\title{
Analysis of cases diagnosed with fetal intracranial anomalies of a tertiary care center
}

\section{Üçüncü basamak bir sağlık kuruluşunda fetal intrakraniyal anomali saptanan olguların analizi}

Savas Karakus ${ }^{1}$, Serife Ozlem Genc ${ }^{1}$, Tahsin Takci ${ }^{1}$, Huseyin Bozkurt ${ }^{2}$, Begum Kurt ${ }^{3}$, Ali Cetin ${ }^{1}$

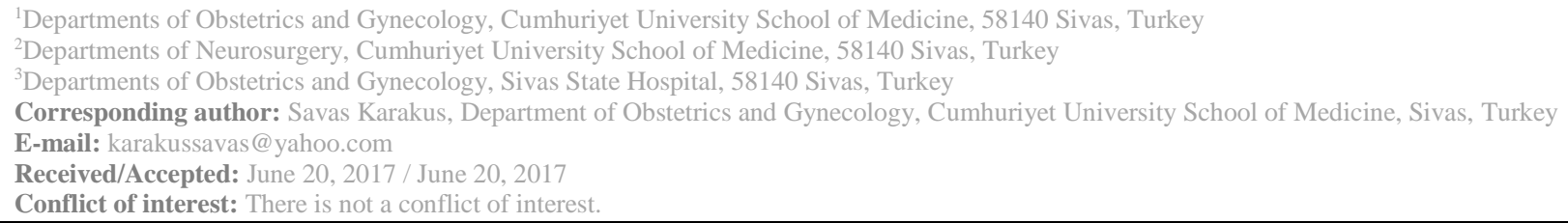

\section{SUMMARY}

Objective: Our aim is to evaluate the analysis of perinatal characteristics of cases diagnosed with fetal intracranial anomaly of tertiary care center over the last 10 years.

Method: A cross-sectional study of 59 pregnant women diagnosed with fetal brain anomalies between 11 and 33 weeks of gestational age (GA). The data were collected from the archive. After that, intracranial anomalies were divided into subtypes and how often they are seen. Descriptive statistics of collected variables were calculated.

Results: 59 cases were diagnosed with an average of $19.3 \pm 5.4$ weeks of gestational age. Karyotype abnormality was detected in $18.6 \%$ of cases. The most common intracranial anomalies in our study were ventriculomegaly (35.6\%), Arnold Chiari malformation (20.3\%) and encephalocele (20.3\%).

Conclusions: Despite the challenges of early gestation, accuracy in diagnosing and counseling to family for fetal brain anomalies before 24 weeks' GA was high. A multidisciplinary approach involving pediatrics, genetics, and neurosurgery, radiology, and obstetrics and gynecology departments is crucial for counseling on perinatal diagnosis.

Keywords : Fetus, intracranial anomalies, karyotype abnormality

\section{ÖZET}

Amaç: Amacımız, son 10 yıl içerisinde, üçüncü basamakta fetal intrakranyal anomali tanısı konan olguların perinatal özelliklerinin değerlendirilmesidir.

Yöntem: Çalışma, kesitsel olarak gebelik haftası 11 ve 33 hafta arasında olan fetal beyin anomalileri saptanan 59 gebeden oluşmakta idi. Veriler arşivden toplandı. Bundan sonra intrakranyal anomaliler alt tiplere ayrılarak görülme sıklıkları belirlendi. Toplanan değişkenlerin tanımlayıcı istatistikleri hesaplandı.

Bulgular: 59 olgunun, gebelik haftasının ortalama $19.3 \pm 5.4$ hafta olduğu tespit edildi. Olguların\% 18.sında karyotip anormalliği tespit edildi. Çalışmamızda en sik görülen intrakranyal anomaliler ventrikülomegali (\% 35.6), Arnold chiari malformasyonu (\% 20.3) ve ensefalosel (\% 20.3) idi.

Sonuç: Erken gebelik haftasında tanının zorluklarına rağmen, gestasyonel yaşın 24 haftasından önce fetal beyin anomalilerine doğru tanı konma oranı yüksekti. Kadın Hastalıkları ve doğum, pediatri, genetik, nöroşirürji ve radyoloji bölümlerini içeren multidisipliner bir yaklaşım, perinatal teşhis için çok önemlidir.

Anahtar sözcükler: Fetüs, kafa içi anomalileri, kromozomal anomali 


\section{INTRODUCTION}

Central nervous system anomalies, which constitute a significant part of the fetal anomalies detected in intrauterine life in human pregnancies, play an important role in perinatology practice ${ }^{1}$. With more general use of ultrasound (US) and then magnetic resonance imaging (MRI), the central nervous system anomaly has been detected and typed in intrauterine life ${ }^{2}$. Early detection of these anomalies, however, leads to be able to both present the termination option to the family as live fetus, and intrauterine treatment option ${ }^{3,4}$. Early termination of pregnancy may reduce possible maternal and fetal morbidity and mortality. These anomalous babies has a significant burden to families and society; that's why, it's important to diagnose antenatally $5,6,7$. In our country, if tertiary care centers establish their experience of fetal intracranial anomalies, this perinatological cause may be well understood and this can provide significant benefits in determining which types are seen more often and in shaping the search for solutions more accurately.

The aim of this study is to evaluate the perinatal characteristics of fetal intracranial anomalies of a tertiary care center over the last decade as a crosssectional study.

\section{MATERIAL AND METHODS}

The study protocol received approval from the $\mathrm{Hu}$ man Research Ethics Committee of our University . Between January 1, 2004 and June 1, 2017 after fetal anomaly scan and routine obstetric USG examination, 59 cases with fetal intracranial anomaly were examined cross-sectionally. All cases were assessed in terms of the life status of the anomalies and the prognosis of pregnancy in the Perinatal Council, which was established with the participation of gynecologists and obstetricians, neurosurgery, child health and diseases, genetics, pediatric surgeon and radiology specialists. Data were obtained from patient files, maternal age, gravida, parity, gestational week, and location of patients, anomalies detected in US or MRI, and results of chromosome analysis.

\section{Statistical analysis}

We calculated descriptive statistics of the collecte $\mathrm{d}$ variables and presented them as mean \pm $\mathrm{SD}$, median (min-max), or percentage. Statistical analysis was performed using IBM SPSS version 22.0 (IBM Corporation, Armonk, NY, USA). A p value of less than 0.05 was considered significant.

\section{RESULTS}

The clinical characteristics of the study group and types of intracranial anomalies are shown in Table 1. The mean maternal age was $28.1 \pm 5.2$ and the gestational week was $19.3 \pm 5.4$. Pregnancies with intracranial anomalies were found to live more in the city center. Abnormal karyotype was present in $18.6 \%$ of these patients. It was determined that polyhydramnios in three, venticulomegaly in twenty one, holoprosencephaly in three, corpus callosum agenesis in three, DandyWalker malformation in one, Arnold Chiari malformation in twelve, anencephaly in six, encephalocele in twelve, mega cisterna magna in two, arachnoid cyst in three, cerebellar agenesis in four and acrania in tenfetuses have these anomalies. 
Table 1. Demographic parameters of study groups.

\begin{tabular}{|c|c|}
\hline Age (y) & $28.1 \pm 5.2$ \\
\hline Gestational age (week) & $19.3 \pm 5.4$ \\
\hline \multicolumn{2}{|l|}{ Pregnancy history } \\
\hline Gravidity (number) & $2.0(1-7)$ \\
\hline Parity (number) & $1.0(0-4)$ \\
\hline Abortion (number) & $0.0(0-2)$ \\
\hline $\mathrm{D} \& \mathrm{C}($ number $)$ & $0.0(0-2)$ \\
\hline \multicolumn{2}{|l|}{ Place of living } \\
\hline Urban & $29(49.2 \%)$ \\
\hline Town & $13(22.0 \%)$ \\
\hline Rural & $17(28.8 \%)$ \\
\hline \multicolumn{2}{|l|}{ Karyotype abnormality } \\
\hline No & $48(81.4 \%)$ \\
\hline Present & $11(18.6 \%)$ \\
\hline \multicolumn{2}{|l|}{ Polyhydramnios } \\
\hline No & $56(94.9 \%)$ \\
\hline Present & $3(5.1 \%)$ \\
\hline \multicolumn{2}{|l|}{ Fetal ventriculomegaly } \\
\hline No & $38(64.4 \%)$ \\
\hline Present & $21(35.6 \%)$ \\
\hline \multicolumn{2}{|l|}{ Holoprosencephaly } \\
\hline No & $56(94.9 \%)$ \\
\hline Present & $3(5.1 \%)$ \\
\hline \multicolumn{2}{|l|}{ Corpus callosum agenesis } \\
\hline No & $56(94.9 \%)$ \\
\hline Present & $3(5.1 \%)$ \\
\hline \multicolumn{2}{|c|}{ Dandy walker malformation } \\
\hline No & $58(98.3 \%)$ \\
\hline Present & $1(1.7 \%)$ \\
\hline \multicolumn{2}{|c|}{ Arnold chiari malformation } \\
\hline No & $47(79.7 \%)$ \\
\hline Present & $12(20.3 \%)$ \\
\hline \multicolumn{2}{|l|}{ Anencephaly } \\
\hline No & $53(89.8 \%)$ \\
\hline Present & $6(10.2 \%)$ \\
\hline \multicolumn{2}{|l|}{ Encephalocele } \\
\hline No & $47(79.7 \%)$ \\
\hline Present & $12(20.3 \%)$ \\
\hline \multicolumn{2}{|l|}{ Mega cisterna magna } \\
\hline No & $57(96.6 \%)$ \\
\hline Present & $2(3.4 \%)$ \\
\hline \multicolumn{2}{|l|}{ Arachnoid cyst } \\
\hline No & $56(94.9 \%)$ \\
\hline Present & $3(5.1 \%)$ \\
\hline \multicolumn{2}{|l|}{ Cerebellar agenesis } \\
\hline No & $55(93.2 \%)$ \\
\hline Present & $4(6.8 \%)$ \\
\hline \multicolumn{2}{|l|}{ Fetal acrania } \\
\hline No & $49(83.1 \%)$ \\
\hline Present & $10(16.9 \%)$ \\
\hline
\end{tabular}




\section{DISCUSSION}

This finding seems to be influenced by the earlier access to the healthcare facility and the higher sociocultural level in the city center, even though it is seen that the fetuses we identified between US and MRI and 11-33 gestational weeks with fetal intracranial anomalies were mostly referred from the city center. As a result of the autopsy, it was determined that a few of these fetuses had abnormal karyotypes. Fetal ventriculomegaly, Arnold Chiari malformation, encephalocele, fetal acrania, anencephaly, arachnoid cyst, holoprosencephaly, corpus callosum agenesis, mega cisterna magna, and Dandy Walker malformation were observed in the intracranial anomalies respectively.

Fetal central nervous system (CNS) anomalies are common and some are incompatible with life, others are life-limiting even if they are compatible with life. US is an effective imaging method for inutero scanning of anomalies including the CNS. More frequent use of MRI in addition to the US is helping to improve diagnostic safety. MR imaging is an important adjunct to prenatal imaging in cases where anomalies are suspected to be difficult to diagnose with US ${ }^{8,9}$.

It is difficult for the fetal brain to be correctly assessed with the US. Depending on the fetal position, it is not always easy to obtain a midline sagittal image. Fetal MRI has many advantages in evaluating posterior fossa abnormalities, particularly in the late pregnancy. The US is often used as a screening method. Additional methods (such as MRI) may be needed for diagnosis if an abnormality is detected. Fetal position or maternal posture may prevent visualization of anomalies. In addition, it may take time for anatomy to be well evaluated and documented ${ }^{10}$.

In their study to determine the prevalence of congenital malformation diagnosed, MolinaGiraldo et al. ${ }^{11}$ found that central nervous system anomalies were the most common among 236 malformed fetuses. Among these anomalies, they demonstrated that the most common anomaly was ventriculomegaly. They found an abnormal karyotype at 38\% of the karyotype analysis. They also concluded that US in prenatal period can be diagnosed in the majority of congenital central nervous system anomalies.

Mansouri et al. ${ }^{12}$ confirmed their postnatal diagnosis of 90 fetuses receiving CNS anomalies in their study. Among them, spina bifida, hydrocephalus, anencephaly, holoprosencephaly, encephalocele, microcephaly and brain cyst were detected according to frequency order. They concluded that CNS anomalies were the cause of significant fetal mortality.

Sefidbakht et al. ${ }^{13}$ have shown Dandy-Walker variant and Arnold-Chiari II as the most common findings in studying fetal CNS anomalies according to subtype frequency. Other findings with lower incidence were corpus callosum, arachnoid cyst, and mega cisterna magna. They concluded that MRI is superior to US in detection of CNS anomalies.

Ghavami et al. ${ }^{14}$ have tried to identify CNS frequency, and associated abnormalities were found in $112 \mathrm{CNS}$ anomalies in 22500 pregnant women. Among them, Chiari malformation, anencephaly, encephalocele, Dandy walker's syndrome, arachnoid cysts, corpus callosum agenesis and holoprosencephaly were detected according to frequency. They suggested that Chiari malformation and hydrocephalus were the most prevalent anomalies of CNS congenital abnormalities.

Wald et al. ${ }^{15}$ established anomalies of the CNS detected by prenatal US and fetal diagnosing abnormalities of the posterior fossa and found that some selected patients' needs additional MRI of the fetal CNS. They found fetuses that had hydrocephaly, Dandy Walker cyst, anencephaly, encephalocele and holoprosencephaly.

In our study, fetal ventriculomegaly, Arnold Chiari malformation, encephalocele, fetal crania, anencephaly, arachnoid cyst, holoprosencephaly, corpus callosum agenesis, mega cisterna magna, Dandy Walker malformation were observed in intracranial anomalies in accordance with the literature.

The limitation of this study is that; we should be more cautious to make a decision about intracranial anomalies which is detected antenatal, because the number of cases diagnosed by US and MRI is small at our center.

In conclusion, when the findings of our research are evaluated in general, it is important to use ultrasonography and MRI together to give more accurate decision in termination of pregnancy and to provide better consultation related to the gestation of the family. In the future, increase in knowledge in the field of fetal MRI and improvement of fetal MRI applications may help to detect intracranial anomalies earlier gestational age. These developments may further reduce the burden of intracranial anomalies in terms of maternal and community health. 


\section{REFERENCES}

1. Köşüş A, Köşüş N, Usluoğulları B, Duran $M$, Turhan NÖ, Tekşam M. Fetal magnetic resonance imaging in obstetric practice. $\mathrm{J}$ Turk Ger Gynecol Assoc 2011; 12: 39-46.

2. Garcia-Flores J, Recio M, Uriel M, Cañamares M, Cruceyra M, Tamarit I, Carrascoso J, Espada M, Sáinz de la Cuesta R. Fetal magnetic resonance imaging and neurosonography in congenital neurological anomalies: supplementary diagnostic and postnatal prognostic value. J Matern Fetal Neonatal Med 2013; 26 : 1517-23.

3. Trudell AS, Odibo AO. Diagnosis of spina bifida on ultrasound: always termination? Best Pract Res Clin Obstet Gynaecol 2014; 28: 367-77.

4. Kahn L, Mbabuike N, Valle-Giler EP, Garces J, Moore RC, Hilaire HS, Bui CJ. Fetal surgery: the ochsner experience with in utero spina bifida repair. Ochsner $\mathrm{J}$ 2014; 14: 112-8.

5. Balakumar K. Antenatal ultrasound screening for anomalies among singletonsresults of a prospective study. Calicut Medical Journal 2004; 2: 1-10

6. Davies V, Gledhill J, McFadyen A, Whitlow B, Economides D. Psychological outcome in women undergoing termination of pregnancy for ultrasounddetected fetal anomaly in the first and second trimesters: a pilot study. Ultrasound Obstet Gynecol 2005; 25: 38992.

7. Iknur Gümüş, Atalay Ekin, Ceren Gölbaş1, Ezgi Hürcan, Cüneyt Eftal Taner. Evaluating 101 cases with the anomaly of fetal central nervous system. Perinatal Journal 2016; 24: 136-141

8. Simon EM, Goldstein RB, Coakley FV, Filly RA, Broderick KC, Musci TJ, Barkovich AJ. Fast MR imaging of fetal CNS anomalies in utero. AJNR Am J Neuroradiol 2000; 21: 1688-98.

9. Emine Aydın, Mert Turgal, Sema Can, Özgür Özyüncü.Posterior fossa anomalies: related anomalies and the methods of pregnancy termination. Perinatal Journal 2016; 24: 89-95
10. Griffiths PD, Bradburn M, Campbell MJ, Connolly DJA, Cooper CL, Jarvis D, Kilby MD, Mason G, Mooney C, Robson SC, Wailoo A; MERIDIAN Collaborative Group. Change in diagnostic confidence brought about by using in utero MRI for fetal structural brain pathology: analysis of the MERIDIAN cohort. Clin Radiol 2017; 72: 451-7.

11. Molina-Giraldo S, Alfonso-Ospina L, Parra-Meza C, Lancheros-García EA, Rojas-Arias JL, Acuña-Osorio E. Prevalence in birth defects diagnosed by ultrasound: three years experience in university maternal fetal medicine unit. Ginecol Obstet Mex 2015; 83: 680-9.

12. Mansouri HA. Central nervous system anomalies diagnosed antenatally and postdelivery management. Saudi Med J 2010; 31: 257-61.

13. Sefidbakht S, Dehghani S, Safari M, Vafaei H, Kasraeian M. Fetal Central Nervous System Anomalies Detected by Magnetic Resonance Imaging: A TwoYear Experience. Iran J Pediatr 2016; 26 : e4589.

14. Ghavami M, Abedinzadeh R. Prevalence of perinatal central nervous system anomalies in East Azarbaijan-Iran. Iran J Radiol 2011; 8: 79-81.

15. Wald M, Lawrenz K, Deutinger J, Weninger M. Verification of anomalies of the central nervous system detected by prenatal ultrasound. Ultraschall Med 2004; 25: 214-7. 